\title{
Science in Revolutionary America
}

\section{INSPIRATION AND ENCOURAGEMENT FROM THE OLD WORLD}

\section{Bernard Caccia}

\author{
"Science was so central to the thought of the Enlightenment and it lay \\ so directly behind the Revolutionary argument, that the men who made \\ the American Revolution were thoroughly committed to the pursuit of \\ science. They were convinced of its utility and confident of America's \\ capacity to achieve in this realm."
}

BROOKE HINDLE

The two-hundredth birthday of a great nation is being celebrated with a certain amount of excitement and is even being graced by the presence of those two illustrious descendants of George III-by now presumably forgiven for his intransigence-Queen Elizabeth and the Duke of Edinburgh. A great deal has been written about the acrimonious political quarrels that led inevitably to the secession of the thirteen little colonies, each somewhat jealous and suspicious of the others, but a lot less has been recorded about the way in which scientific methods were first implanted in the American colonies and then helped to flourish. But from its present position of world leadership in technology it is an interesting exercise to look back to the America of the colonial era, when science was just beginning to attract the minds of a few pioneers, and to the slow and sometimes painful growth of scientific ideas and institutions up to the time of the revolution and the early days of the republic. A succession of outstanding men, living and working on both sides of the Atlantic, and spread over only about three generations, can be seen to have inspired and encouraged each other and to have formed a network of enthusiasts which helped significantly in transforming the climate of American thought.

\section{The Role of the Royal Society}

As Governor John Winthrop wrote in 1668, "there were all thinges to doe as in the beginninge of the world". For many years every man was absorbed in establishing himself in a remote, underpopulated and often hostile land, yet this same John Winthrop, the first Governor of Connecticut and the son of the first Governor of Massachusetts, was elected a Fellow of the Royal Society in 1661. This was three years before the British annexed New Amsterdam and colonised New Jersey, so linking the colonies of New England with the even older southern colonies in one continuous coastal strip, and more than twenty-five years before Newton laid down the method of pro- gression from experiment to hypothesis in the Principia. And it is to the Royal Society that special credit must be given for its early encouragement, not only of Winthrop but of a whole succession of scientifically minded men in the colonies. Winthrop himself, whose interests included alchemy, chemistry and medicine, circulated the Philosophical Transactions - the first regular medium for the publication of scientific observations in English-among his circle of friends, and generally tried to spread an interest in the methods of experimental science in New England. (Among his many activities was the search for useful mineral deposits, and it was from one of his specimens, later sent home by his grandson to Sir Hans Sloane, then President of the Royal Society, that the English chemist Charles Hatchett was to isolate the new element which he gracefully named Columbium-the first time that an element was named after a country-but now and perhaps rather sadly re-christened Niobium.)

Much of the "scientific" work of the next few decades was largely confined to the collection of new species of plants and animals and to observations of the climate, the tides and other natural phenomena, all of great interest to the Royal Society but not yet able to be described as truly scientific. None the less the Fellows were active in furthering these efforts, and by their correspondence, the supply of books and the exchange of observations, they steadily nurtured the growth of scientific thought.

Boston, the earliest major settlement in New England, not unnaturally became the intellectual capital of the colonies, and it was because of this accepted position that the first suggestion for forming a colonial scientific society was put forward by Cadwallader Colden, a graduate of Edinburgh University who had left Philadelphia for New York in 1718 to become Surveyor-General and later Lieutenant-Governor and who was widely known to scientists in both Britain and America. In a letter to his old friend and fellow Scotsman Dr. William 


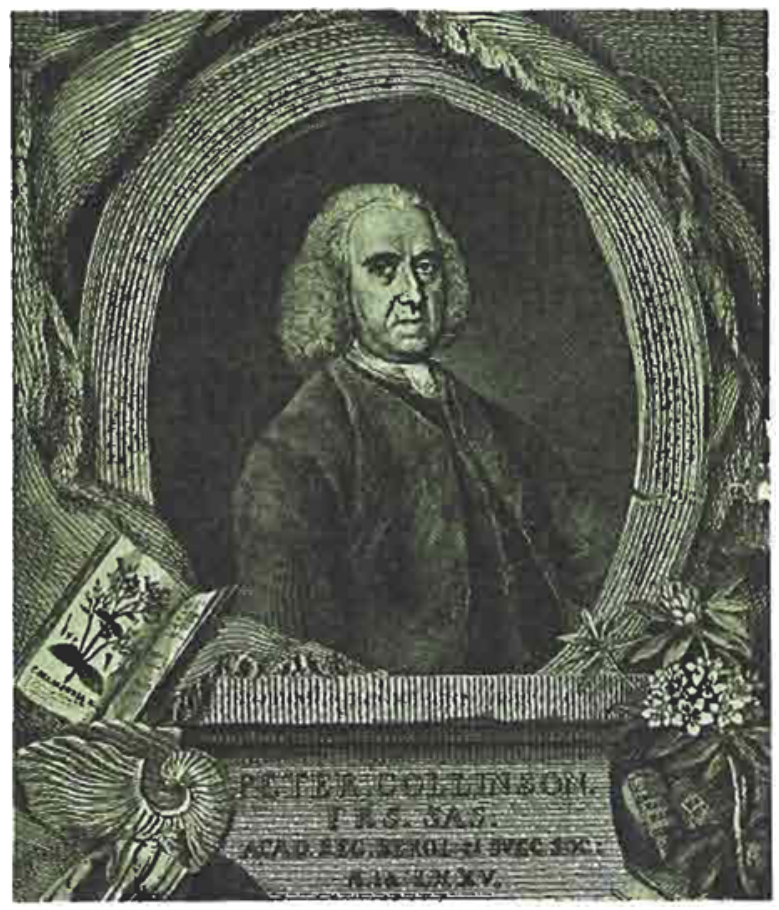

Douglass in 1728 Colden proposed that "a certain number of Men would enter into a Voluntary Society for the advancing of Knowledge", and that Boston would be the most suitable location as it had "the greatest number of proper persons". The idea was not taken up, but in 1736 Douglass did in fact organise a socicty of medical men in the Boston area. This was the first such body to be formed, and it led the way for a number of American learned societies designed to supplement the role of the Royal Society, of which seven colonials were by now Fellows, including Elihu Yale and Cotton Mather.

Another Bostonian, Isaac Greenwood, a student of Cotton Mather's and a graduate of Harvard, visited England in 1723 where he engaged in conversation with Isaac Newton and became friendly with Jean Théophile Desaguliers, the French physicist who had settled in London and had become Curator of Experiments at the Royal Society. After a period as assistant to Desaguliers, Greenwood returned to

\section{Benjamin Franklin $1706-1790$}

The first American to be recognised as the equal of leading scientists in Europe, Franklin made a major contrilution to modern physies, developed a theory of electricity and introduced many of the elcetrical terms still used today. In his later years he greatly influeneed the exchange of ideas and observations between seientists in Europe and those in the colonies. At the age of 70 he was the oldest and most eminent of the men who sigued the Declaration of Independence

\section{Peter Collinson \\ 1694-1768}

The London cloth merchant who not only initiated Franklin into the study of electricity but also introduced his remarkable experimental work to the wider public of European science. Elected to the Royal Society in 1728 , he served on the council for over thirty years and was on terms of close friendship with many of the leading personalities of his time including Lord Bute, the Duke of Northumberland, botl the second and the third Dukes of Richmond and Sir Hans Sloane, as well as with scientists such as William Watson and John Fothergill

Boston with a collection of scientific apparatus to teach and lecture in the style of his mentor, and managed to get himself appointed the first Professor of Mathematics and Natural Philosophy at Harvard. His public lectures and demonstrations were so successful that the pattern was soon followed in other colonial colleges as well as by a number of travelling public lecturers. Yale, under the influence of its President Thomas Clap, an ardent admirer of Newton, also reorganised its curriculum with a greater emphasis on science.

Greenwood's tenure of his chair at Harvard was shortened by his addiction to drink, but among his contributions to science in New England there stands out his part in bringing on one of his students, John Winthrop, the great-grand-nephew of John Winthrop the Younger, who succeeded Greenwood in the chair at Harvard in 1738 at the age of 24 and held it until his death in 1779 , bringing distinction to the study and teaching of physics and mathematics. By 1746-one year before Franklin embarked on his

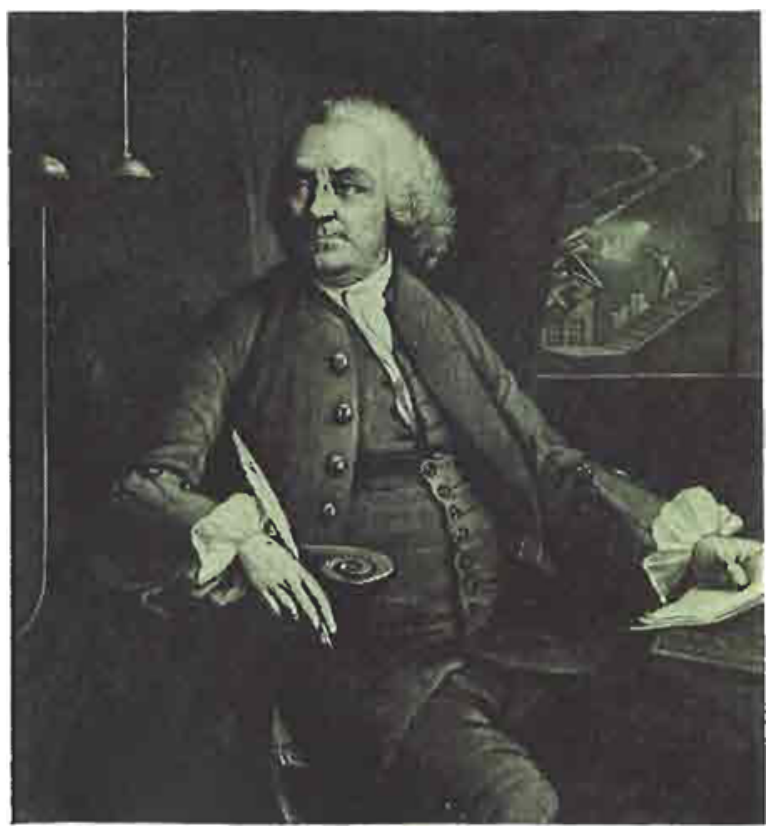


famous series of experiments-he had included one lecture on electricity in his course of "Philosophical Lectures".

In the earlier years of the American colonies very few in England could foresee the great possibilities that lay ahead. (One who had an eye for the future was a Sir Winston Churchill, an impoverished officer in the Guards who had fought for Charles I against Cromwell's armies and the ancestor of his more famous namesake, who wrote in 1675 of "those far-distant regions, now become a part of us and growing apace to be the bigger part, in the sun-burnt America".)

By many the colonies were regarded merely as a valuable market for the export of English woollen cloth, and it was in fact a cloth merchant who was to play a singularly important part not only in the introduction of scientific method to the colonies but in publicising its results back in the mother country. This was Peter Collinson, who entered his father's cloth business in London but who devoted a great deal of his time to scientific matters, became a distinguished botanist, and was elected to the Royal Society in 1728 , serving on its council for over thirty years.

In the course of his extensive correspondence and successful trade with the American colonies, Collinson, unlike his competitors, actively encouraged the glimmerings of scientific study that he detected among some of his clients, and it was to Collinson that Benjamin Franklin turned when he founded his Library Company in 1731. By this time Philadelphia, then the second largest city in the colonies, was becoming a rival to Boston as a centre of inquiring minds, although the shortage of books was even more acute than in the older city. Many years later, after Collinson's death, Franklin described him as

\begin{abstract}
"a judicious friend in London who voluntarily and cheerfully undertook for more than thirty years the choosing, collecting and shipping of books and who regularly sent over the earliest accounts of every European improvement in agriculture and the arts and every philosophical discovery".
\end{abstract}

Philadelphia had been the home of Benjamin Franklin-the thirteenth son of a soap boiler and tallow chandler who had emigrated from Banbury in England-since as a boy of 17 he had deserted his native Boston in 1723 and-after a visit to London where he met Sir Hans Sloane but failed in his desire to meet the ageing Newton-had established himself as a master printer. By the time he was 40 , however, Franklin had begun to think of retiring from business "to enjoy life and my friends", and had found himself a partner and potential successor. Two years later, in 1748 , he achieved his ambition, and wrote that he hoped now to have "leisure to read, study, make experiments, and converse at large with ingenious and worthy men".

Overlapping this wish to retire and its achievement he began that astonishing phase of his career-lasting only seven or eight years-in which he made fundamental contributions to the new science of electricity and established himself as the outstanding scientist of his century.

Meanwhile, in 1743, Franklin had urged the formation of a scientific society in America in a pamphlet bearing the title $A$ Proposal for Promoting Useful Knowledge among the British Plantations in America. The outcome was the American Philosophical Society, with Franklin as its secretary, but lacking strength and resources this gradually faded away, to be reborn some twenty-five years later.

\section{Franklin's Introduction to Electricity}

The story of Franklin's introduction to electricity is well known, although some of the details are still a matter of debate. On a brief visit to Boston in 1743 he had met a Dr. Archibald Spencer, a Scotsman and one of the numerous travelling lecturers in "experimental philosophy" who were following in Isaac Greenwood's footsteps. Franklin was not apparently impressed by Spencer's performance, and although he agreed to sponsor his lectures in Philadelphia-as he had sponsored Greenwood earlier-it was not until three years later that his interest was really aroused.

Some time during 1746 Collinson, by now himself taking an active interest in electricity, sent to Franklin a lengthy article from The Gentleman's Magazine of April 1745, "An Historical Account of the Wonderful Discoveries made in Germany etc. Concerning Electricity". This article, unsigned but probably written by William Watson, then the leading authority on the subject in England, opened with a description of the discovery by Otto von Guericke, the Burgomaster of Magdeburg, that

\footnotetext{
"the rotation of a globe of sulphur gave it the same virtue which the ancients had experienced in yellow amber in attracting and repelling alternatively thin and light bodies such as chaff, thin bits of paper, or leaf gold",
}

and went on to describe the discovery by the Englishman Stephen Gray - another associate of Desaguliers -who used a crude form of gold leaf electroscope to show that electricity could be conducted along wires, the improved frictional machines devised by the English physicist Francis Hauksbee, the Frenchman Charles François de Fay, and the later improvements introduced by Christian Hausen and Johann Winkler, both professors at Leipzig, and by Georg Bose, Professor of Physics at Wittenberg, together with an account of some of the experiments made with these machines. 


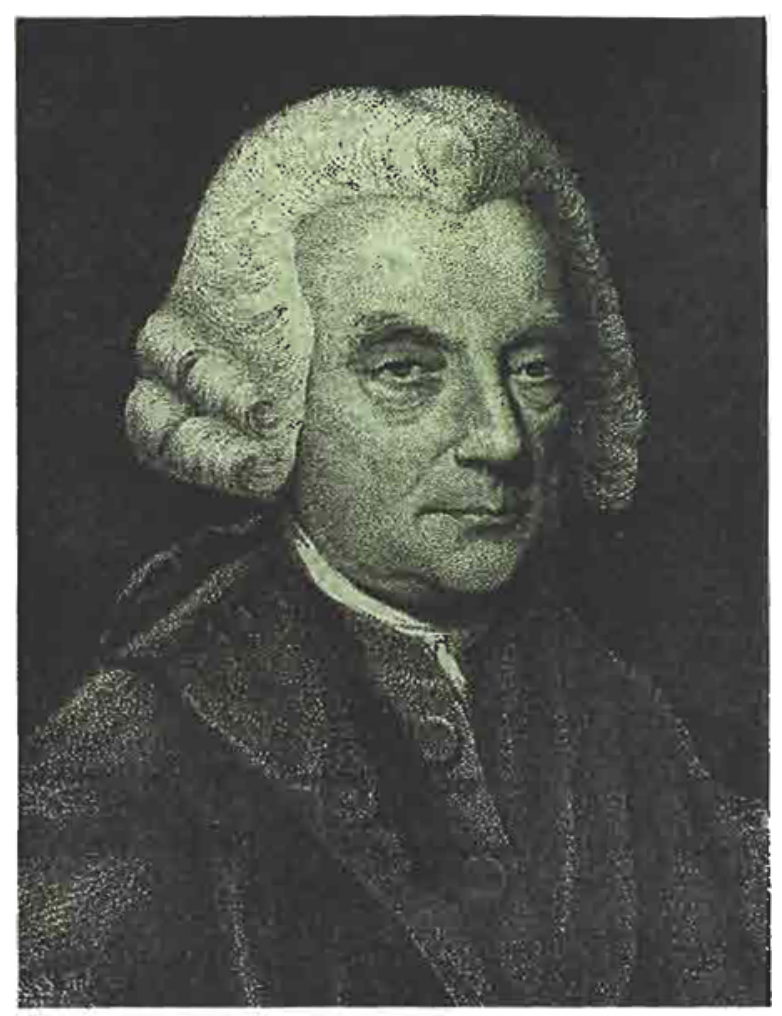

Accompanying this article was a present of a long glass tube such as Watson had used extensively in his experiments, together with directions for its use. Franklin at once embarked on the series of experiments-interrupted by his organisation of a volunteer militia for the defence of Pennsylvania against the threat of attack by French privateers sailing up the Delaware River-that were to make him famous throughout Europe before he was recognised as a scientist in his own country.

A little later, Thomas Penn, son of the founder of Pennsylvania and now himself the "Proprietor" of the colony, made Franklin a present of "a compleat electrical apparatus", but the crucial point in Franklin's work was undoubtedly the introduction of what is now known as the Leyden jar-the first means of storing an electric charge, or in other words the first capacitor-a step which at once greatly increased the energy available to the experimenter. Invented almost simultaneously by Ewald Georg von Kleist, dean of the cathedral in the small Prussian city of Kammin in October 1745, and, in January 1746, by Pieter van Musschenbroek, Professor of Mathematics at the University of Leyden, it was described by the latter in a letter to Réamur, who at once communicated it to the Académie Royale des Sciences. Equally rapidly it was reported by Winckler in Germany and by the Abbé Nollet, Musschenbroek's friend, in his Essai sur l'Electricité des Corps published in Paris, also in 1746. In 1745 Watson had published a small book, Experiments and

\section{Sir William Watson}

171.5-1787

When Franklin embarked on his series of electrical experiments in $\mathbf{1 7 4 6}$ Watson was already the leading authority on the subject in England and it was his publications, sent over by Peter Collinson, that formed the starting point for Franklin. A London apothecary and physician, Watson reported some of Franklin's early experiments to the Royal Society and later contributed a complimentary review of his collected work. He first demonstrated the passage of clectricity through a vacuun. For his many original papers on electricity and other subjects presented to the Royal Society he was knighted in 1786

Observations Tending to Illustrate the Nature and Properties of Electricity, followed a year later by $A$ Sequal to the Experiments and Observations, the latter containing a description of the Leyden jar, and both had been sent across to Franklin by Collinson, who also regularly forwarded the Philosophical Transactions as soon as they appeared. By September 1747 Franklin was describing his experiments with " $M$. Musschenbroek's wonderful bottle" in the famous series of letters to Collinson.

These letters were shown to Collinson's friends, particularly to Watson and to Dr. John Fothergill, a Yorkshire Quaker and physician, and in a long paper read to the Royal Society in January 1748 Watson included an extract from the first of these letters, introducing it as follows:

"Mr. Collinson, a worthy Member of this Society has received a Paper concerning Electricity from an ingenious Gentleman, Mr. Franklin, a Friend of his in Pennsylvania. This Paper, dated June, 1747, I very lately perused, by Favour of our most worthy President."

In the course of this letter-the first communication from Franklin to be published in the Philosophical Transactions-he introduced the terms "electrised positively" and "electrised negatively" and the abbreviated forms "plus" and "minus".

In the same letter, but not in the extract quoted by Watson, he wrote:

"We had for some time been of opinion, that the electrical fire was not created by friction, but collected, being really an element diffus'd among, and attracted by other matter, particularly by water and metals".

This, the first indication of how Franklin's theory of electricity was developing in his mind, was followed in a later letter to Collinson in July of 1750 , in which he began:

"The electrical matter consists of particles extremely subtile, since it can permeate common 


\section{Franklin Discovers the Contact Properties of Gold}

One of Franklin's many electrical experinents was his demonstration, in 1747, of the outstanding contact properties of gold and of its high conductivity. Using a Leyden jar, a book having gold filleting on its binding and a bent piece of wire, he found that "the passing of the electric fire from the upper to the lower part of the bottle to restore the equilibrium" was greatly facilitated when the end of the wire was in contact with the gold. "The closer the contact between the shoulder of the wire, and the gold at one end of the line, and between the bottom of the bottle and the gold at the other end, the better the experiment will succeed"

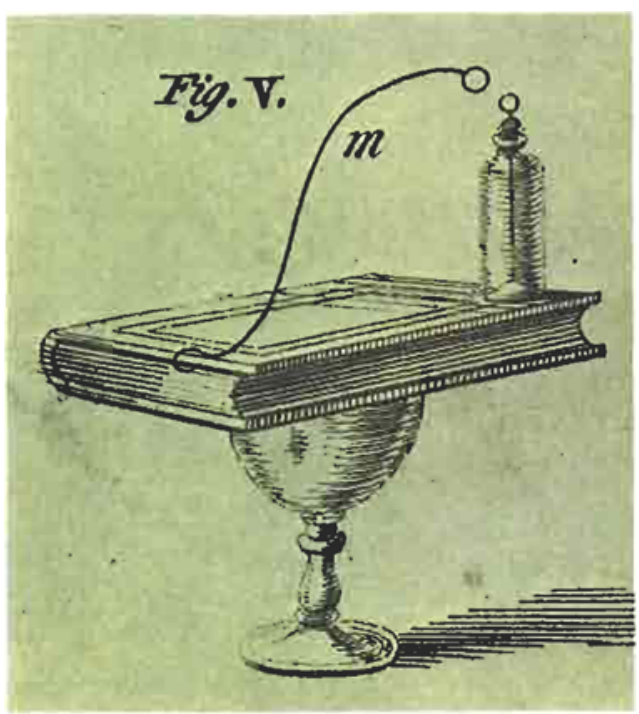

matter, even the densest metals, with such ease and freedom as not to receive any perceptible resistance ... Thus, common matter is a kind of spunge to the electrical fluid"

This "one fluid" theory of Franklin's (he now dropped the phrase "electric fire") was of course his major contribution to the whole subject of electricity, although it aroused opposition in some quarters, notably from the Abbé Nollet, who was now virtually Court Electrician to Louis XV and who held to a "two fluid" theory, but stalwart support was forthcoming from the French physicist Jean-Baptiste Le Roy and from Giambatiste Beccaria, Professor of Physics at the University of Turin, as well as from many others.

The remarkable reasoning displayed by Franklin in advancing the "one-fluid" theory is even more astonishing when one remembers that at this time Volta was a five-year-old child and that a continuous current of electricity was still half a century away, A century and a half later, Sir J. J. Thomson commented after his discovery of the electron:

"A collection of electrons would resemble in many respects Franklin's electric fluid."

Franklin's long series of experiments cannot of course be detailed here. They ranged from his demonstration that lightning was identical with the electric discharge (to simulate lightning in his early work he "passed the wire in the dark over a china plate that has gilt flowers"), to his discovery, illustrated here, that gold was an excellent conductor and an equally good contact material, and to his attempts to melt copper, silver and gold by the discharge, considering that this occurred by a kind of cold fusion-_a fusion without heat". In using the gilding on a book he also found that "though at first it communicated the shock perfectly well, yet failed after a few experiments, which we could not account for. We have since found that one strong shock breaks the continuity of the gold in the filleting, and makes it look rather like dust of gold, abundance of its parts being broken and driven off; and it will seldom conduct above one strong shock. Perhaps this may be the reason: When there is not a perfect continuity in the circuit, the fire must leap over the vacancies. There is a certain distance which it is able to leap over according to its strength"

Franklin also experimented with the deflection of a piece of gold leaf suspended between two plates, one electrified and one grounded-the forerunner of the means of measuring the intensity of a charge, the gold leaf electroscope finally developed by the English curate Abraham Bennett in 1786-while he recognised that good electrical conductors are also good conductors of heat.

Franklin's papers were not published in full by the Royal Society, and Fothergill urged Collinson to arrange for their separate publication. They were handed to Edward Cave, the founder and publisher of The Gentleman's Magazine, but instead of including them in his monthly journal he preferred to issue them in book form, and they appeared in 1751 as Experiments and Observations on Electricity Made at Philadelphia in America, with a preface by Fothergill in which he wrote that he

\footnotetext{
"was prevailed upon to commit such detached pieces as were in his hands to the press without waiting for the ingenious author's permission so to do"
}

On June 6th, in the same year Watson read to the Royal Society a review of the book, running to considerable length, and concluding: 


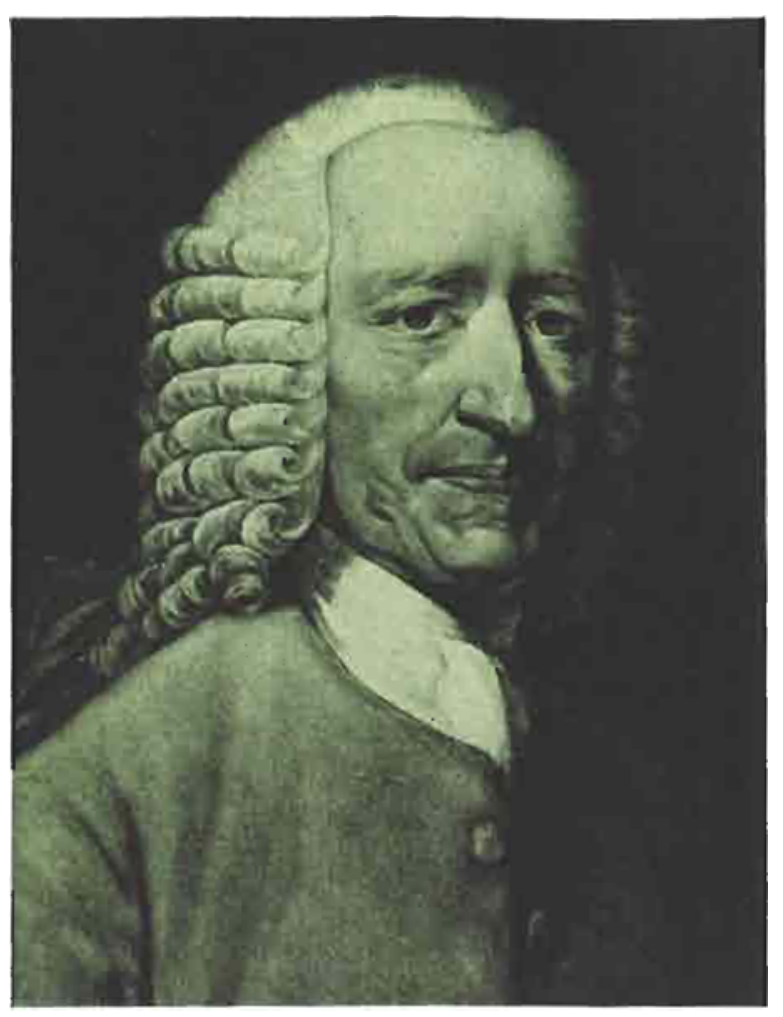

"Upon the whole, Mr. Franklin appears in the work before us to be a very able and ingenious man; that he has a head to conceive, and a hand to carry into execution, whatever he thinks may conduce to enlighten the subject-matter, of which he is treating: and altho' there are in this work some few opinions, in which I cannot perfectly agree with him, I think scarce any body is better acquainted with the subject of electricity than himself'

The book ran to five English editions (additional material being added) and to three editions in French, one in Italian, one in German-and even one in Latin-but it was not published in America until the appearance of Professor I. Bernard Cohen's critical edition of 1941 !

In 1753 the Royal Society awarded Franklin the Sir Godfrey Copley gold medal, the highest distinction the Society has to bestow, for his "curious experiments and observations on electricity", and followed this by electing him a Fellow in 1756. As his principal biographer Carl Van Doren writes: "He found electricity a curiosity and left it a science".

\section{The Three Collaborators}

In writing to thank Peter Collinson for his gift of a glass tube in 1746 Franklin said that he had

"caused a number of similar tubes to be blown at our glass house with which they furnished themselves so that we had at length several performers".

Among these were his three principal collaborators, Philip Syng, Thomas Hopkinson and Ebenezer

\section{John Fothergill \\ 1712-1780}

A Yorkshireman and a Quaker, John Fothergill took a medical degree at the University of Edinburgh and practised at St. Thomas's Hospital in London. He was instrumental in the publishing of Franklin's letters on electricity and, like Watson, became his close friend during the London period. Fothergill collaborated with Franklin in urging the repeal of the Stamp Aet and in drawing up a scheme of reconciliation with the colonies. He was also active in welcoming young men from the colonies arriving in England to study medicine and in advising them on their studies

Kinnersley, and Franklin was punctilious in giving them credit in his letters. Syng, born in Cork in Ireland in 1703 the son of a goldsmith and silversmith, came to America with his parents and eventually succeeded his father in the workshop close to Franklin's house in Market Street. He first appears as the inventor of "a simple easily made machine designed to avoid the fatiguing exercise frequently spoken of in the European papers", doubtless the outcome of his silversmithing skill, in which "our spheres are fixed on iron axes, which pass through them. At one end of the axis there is a small handle, with which you turn the sphere like a common grindstone".

Examples of Philip Syng's silver work are preserved in a number of American museums, but his most famous piece is the silver ink-stand made in 1752 for the Provincial Assembly of Pennsylvania and used 24 years later at the signing of the Declaration of Independence.

Thomas Hopkinson, a lawyer born in London in 1709, had established himself in Philadelphia and had been chosen first President of the infant American Philosophical Society; it was he who first demonstrated "the wonderful effects of pointed bodies both in drawing off and throwing off the electrical fire", so leading on to proposals for lightning conductors made by Franklin, whose first idea for these was

"a rod of iron 8 or 10 feet in length, sharpen'd to a point like a needle, and gilt to prevent rusting".

set out in a letter to Peter Collinson published in The Gentleman's Magazine in May 1750. Hopkinson's early death in 1751 cut short a promising career in both scientific work and public service.

The third and most active collaborator, Ebenezer Kinnersley, was born in Gloucester in England in 1711 and had also been brought to Philadelphia as a child. He was brought up in an ardently Baptist family and had trained for the ministry, but on account of his forthright and outspoken manner had never succeeded in obtaining a congregation of his own. 
Franklin had printed some of his tracts, and finding him without employment encouraged him to devote more of his time not only to electrical experiments but to lecturing on the subject, an activity he began as early as 1749 . Of the three collaborators, Kinnersley was to become the leading experimenter after Franklin himself, and even to correct the master in one important matter-that of the fusion of metals by the electric discharge.

While Franklin was in England between the years 1757 and 1762 as Agent for the Assembly of Pennsylvania he received a letter from Kinnersley (which he read to the Royal Society and which later appeared in the Philosophical Transactions) describing an "electric air thermometer" he had devised and going on to describe his experiment on the melting of wires by the electric charge:

"Hence it appears, that the electric fire, tho' it has no sensible heat when in a state of rest, will, by its violent motion, and the resistance it meets with, produce heat in other bodies, when passing thro' them, provided they be small enough ... Hence lightning does not melt metal by a cold fusion, as we formerly supposed."

Kinnersley was the only American scientist besides Franklin to make a significant contribution to the understanding of electricity in this period.

\section{Franklin in London}

In 1757 Franklin arrived in the London of Pitt the Elder at the height of his powers. The colonies were still united to the mother country and devoted to Pitt (Fort Duquesne, captured from the French in 1759, was promptly re-named Pittsburgh). This was also the London of Oliver Goldsmith and Joshua Reynolds, of Samuel Johnson and David Garrick, but Franklin sought other company among more scientifically minded and radical men. During this visit, lasting five years, he gradually established himself among a circle of friends that included William Watson, John Fothergill, John Canton and John Pringle (later to become President of the Royal Society) as well as his long-standing correspondent Peter Collinson. He was able to visit the Low Countries and to enjoy a discussion with Musschenbroek whose "bottle" he had done so much to understand and improve, and he also visited Edinburgh and met William Cullen, the great professor of chemistry, with whom he discussed the cooling effect of evaporation, on which both of them had carried out experiments. He was again in London for the coronation of George III who he then regarded as "a virtuous generous young king".

It was also during this period in London that he took an active part in the affairs of the Society for the Encouragement of Arts, Manufacturers and Commerce (now the Royal Society of Arts), founded

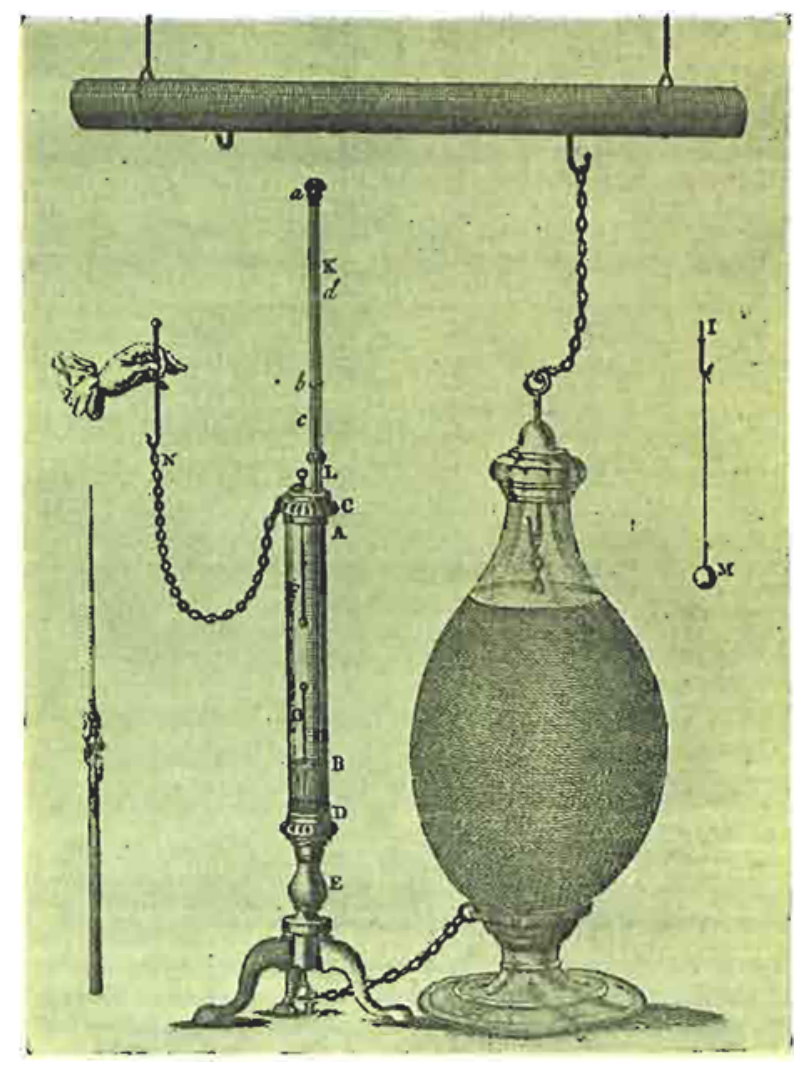

The apparatus devised by Ebenezer Kinnersley described in his letter to Franklin in 1761 and published in the Philosophical Transactions of the Royal Society in 1763. He described it as an air thermometer which "is extremely sensible of any alteration in the state of the included air, and fully determines that controverted point, whether there be any heat in the electric fre" and showed that metal wires could be melted by the diseharge

in 1754 by William Shipley with the support of Stephen Hales as a less sophisticated and more utilitarian body than the Royal Society, and as an important representative of the colonies he was frequently asked to take the chair. The Society, inspired by Franklin and Robert Dossie, the author of the well known Handmaid to the Arts, offered monetary prizes or premiums for establishing, among other processes, the manufacture of potash in the colonies, where it was needed for the production of soap and of glass and for use in bleaching and dyeing. The spirit behind this form of encouragement of new techniques was expressed in a letter from the secretary of the society, Dr. Peter Templeman, to a number of scientists in America in 1760:

"The surest method of improving Science is by a generous intercourse of the Learned in different Countries, and a free communication of Knowledge."

Franklin's interest in this scheme did not fall off after his return to America in 1762, and he reported back to the Society on its progress. 


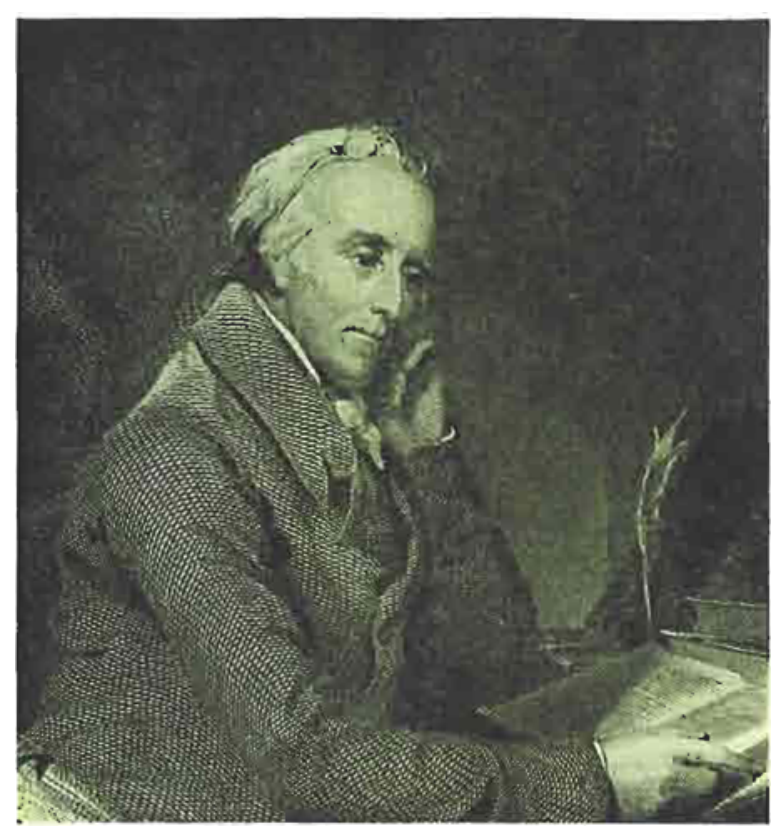

Benjamin Rush

1745-1813

A native of Philadelphia, Rush graduated from the University of Edinburgh in 1768 and regarded his years there as having the most important influence on his life. In the following year he was appointed the first Professor of Chemistry in the American colonies on the recommendation of Fothergill, and he wrote the first American text book on chemistry. In 1776, as a member of Congress for Penusylvania, he signed the Declaration of Independence, and during the war served as Surgeon-General of the Continental Army

By 1764 Franklin was back in London, this time for a stay of ten years until his hasty and tearful departure on the eve of the outbreak of war. His active work as an experimenter long since over, he now took up his role in the promotion of science and in establishing communications between men of science on both sides of the Atlantic, and he conducted a voluminous correspondence to this end. He was four times elected to serve on the Council of the Royal Society and presented a number of papers from his American friends as well as proposing some of them for Fellowship. He purchased apparatus and instruments for Winthrop, as he had done on his earlier visit. He also built up a friendship with the young Earl of Shelburne-then Secretary of State for the Colonies and much later on to become Prime Minister and a man of enlightened views on the problems of the colonies-who was to become the patron of Joseph Priestley, in part at least on Franklin's suggestion.

Priestley had come to London at Christmas 1765 with a letter of introduction to John Canton, who at once introduced him to both Watson and Franklin, to whom he outlined his plan to write a history of "experimental philosophy", beginning with electricity. Franklin gave him every encouragement as well as a number of suggestions for further experiments, and also supported him in his desire to be elected to the Royal Society. By 1767 the task was completed, Franklin and Canton having reviewed the manuscript as it came along, and it achieved an immediate success. The friendship, as with so many others, was to last for very many years and to involve Franklin in chemical as well as electrical discussions.

\section{The First Professor of Chemistry}

Although there had been some rudimentary instruction in chemistry at Harvard towards the end of the seventeenth century, based upon Charles Morton's Compendium Physicae, the first professor of chemistry to be appointed in the colonies was the famous Benjamin Rush. A native of Philadelphia, he arrived at the University of Edinburgh-then the leading university open to dissenters, as Oxford and Cambridge insisted on religious conformity-to study under William Cullen, to whom Franklin had recommended him. Cullen, one of the first to treat chemistry as a subject in its own right, separated from materia medica, was about to relinquish his chair, to be succeeded by his friend and disciple Joseph Black, so that it was under Black that Rush, to be followed by a number of others from the colonies, learnt his chemistry. He graduated in 1768, stayed with Franklin in London for a while and in the following year returned to Philadelphia with a letter of recommendation from John Fothergill to the Trustees of the College of Philadelphia, and also a letter from Thomas Penn:

"Dr. Rush having been recommended to me by Dr. Fothergill as a very expert Chymist, and the Doctor having further recommended to me a chymical apparatus as a thing that will be of great use, particularly in the tryal of ores. I send you such as Dr. Fothergill thought necessary, under the care of Dr. Rush, which I desire your acceptance of. I recommend Dr Rush to your notice, and humbly wishing success to the College, remain with great regard.

$$
\begin{gathered}
\text { Your very affectionate friend, } \\
\text { THOMAS PENN" }
\end{gathered}
$$

Rush lectured for many years at what is now the University of Pennsylvania and in 1770 published the first American text book, $A$ Syllabus of a Course of Lectures on Chemistry. He remained in touch with Franklin; in 1773 for example, Franklin sent him a copy of Priestley's paper "Observations on Different Kinds of Air", as he sent other communications both to Rush and to John Winthrop at Harvard.

But in 1775 everything was interrupted by the outbreak of war. The buildings at Harvard and at the College of Philadelphia were taken over as barracks or hospitals, and the momentum of science and its 
Antoine Laurent Lavoisier

1743-1794

During a long association while Franklin was in Paris, Lavoisier, the founder of modern chemistry, introduced him to the newer ideas and through hin conveyed them, and the reformed nomenclature of cliemistry, to Franklin's many scientific friends in America. In his last letter in $\mathbf{1 7 9 0}$ Lavoisier pleaded with Franklin to support the anti-phlogistic school and wcnt on to express his regret that Franklin was no longer available to offer advice in the political revolution in France

teaching naturally suffered severely, not to be recovered until well into the 1780 's.

Similarly the American Philosophical Society, revived in 1769 with Franklin as President, was gravely affected. The first volume of their Transactions, published in 1771 , was well received by the Royal Society and by other bodies, but the second volume had to wait until after peace had been established and did not appear until 1786.

\section{The Revolution in Chemistry}

By a curious coincidence and the fortunes of politics and war, Franklin, the prime mover in the new science of electricity as well as one of the leaders in the revolution of the colonies, spent the formative years of the revolution in chemistry in the very city of its inception, the Paris of the Enlightenment.

While he was still in London Franklin had come to hear of Lavoisier's early work-the study of combustion and the calcination of metals was not begun until 1772-for in a letter to the French physicist Jean Baptiste Le Roy in June of 1773 he wrote:

"We have nothing here in the philosophic way. I shall like to hear how M. Lavoisier's Doctrine supports itself as I suppose it will be controverted"

It is possible or even likely that Franklin met the much younger Lavoisier during a short visit to Paris in 1769, while he had been elected a foreign associate of the Académie Royale des Sciences in 1772. In any case, by April 1774 Lavoisier forwarded two copies of his Opuscules physiques et chymiques-his first account of experiments on oxidation - to Franklin in London, one for himself and the other for the American Philosophical Society. The accompanying letter contained a graceful reference to the work on gases of Stephen Hales, Joseph Black, Henry Cavendish and Joseph Priestley:

"C'est en angleterre que cette théorie a pris naissance le fond de cet ouvrage appartient donc a votre nation"

(The reference to England would not have amused the Scotsman Black!)

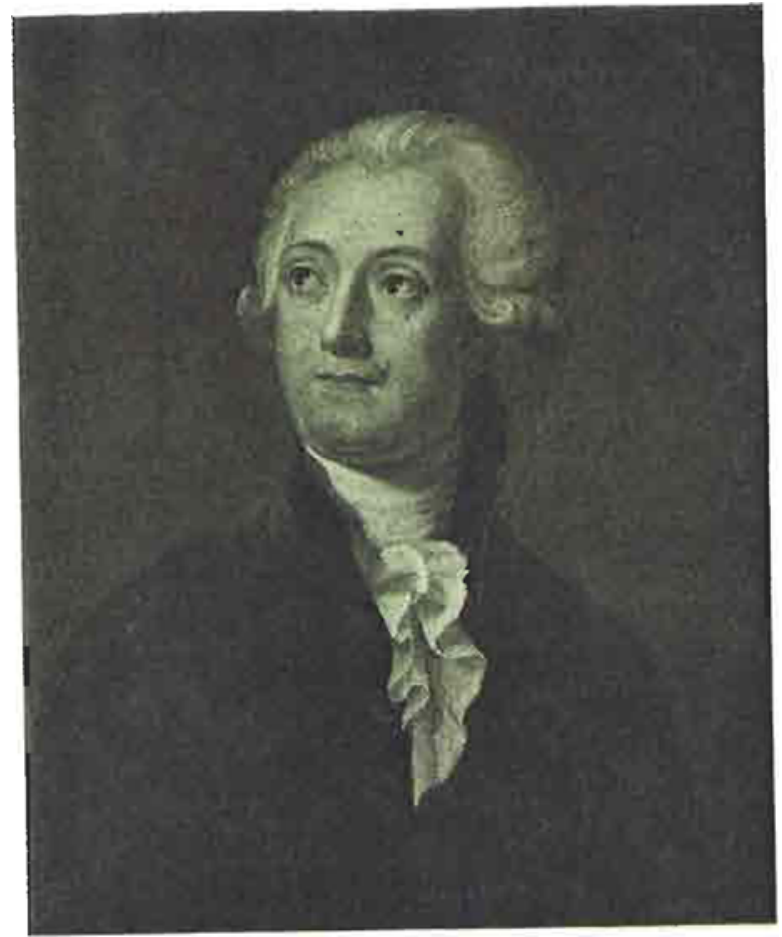

Priestley, who had discovered oxygen, or "dephlogisticated air" as he called it, in August 1774, visited Paris in October of that year with his patron the Earl of Shelburne and described his experiments to Lavoisier, who at once appreciated their significance and pressed on with his experimental work.

Two years later, after the signing of the Declaration of Independence, Franklin, now aged 70, and after the usual uncomfortable voyage lasting about six weeks, arrived in Paris to great acclamation to begin a stay of nine years as the emissary of Congress. At once he set about acquiring a circle of friends, both political and scientific. By June 1777 he had become sufficiently friendly with Lavoisier to be invited to the Arsenal (where Lavoisier had established both his house and his laboratory upon his appointment to the Gunpowder Commission) to witness a repetition of some of Priestley's experiments on "different kinds of air". Here, and at the meetings of the Académie, he met a number of distinguished scientists, including his old friend Le Roy, Balthasar Georges Sage, the analyst and mineralogist, who presented him with a copy of his L'Art d'Essayer l'Or et L'Argent, Pierre Auguste Adet, afterwards to become French Ambassador to the United States, Guyton de Morveau, Pierre-Joseph Macquer, the senior French chemist of his time and the author of the Dictionnaire de Chymie, as well as E. I. du Pont de Nemours, later to be the founder of the great chemical concern in America. From many of these he received original papers and books and relayed them to his friends in America such as Winthrop and Rush. 
Over the next few years Lavoisier continued his experiments, and slowly developed his new ideas, in the course of a long series of papers submitted to the Académie.

At this time he believed that oxygen was formed from oxygen base and what he called caloric, the imponderable element causing the sensation of heat that was released in combustion or oxidation:

"All the metals do not have the same degree of affinity for oxygen. Gold and silver, for example, and also platinum, cannot take it away from its combination with caloric even in the greatest known heat."

By 1783 he had mounted a formidable attack on the phlogistonists, who believed that calcination or combustion was attributable to the escape of phlogiston, the essential element of all combustible matter, and that a metal was a compound of its calx and phlogiston. The controversy was to rage for a considerable time on both sides of the Atlantic.

Among the younger chemists with whom Lavoisier was associated was Antoine François de Fourcroy, who began lecturing on chemistry in 1778 and who, by 1785 , had been converted to the new chemistry and had begun to teach it, as had Black in Edinburgh. Fourcroy-the first to use the phrase "chemical revolution"-was also a prolific author, and after publishing his successful Leçons Éléméntaires d'Histoire Naturelle et de Chimie in 1782 he produced four years later an enlarged and revised edition, Elémens d'Histoire Naturelle et de Chimie, in which he definitely adopted the anti-phlogistic theory. Both were translated into English and undoubtedly reached America. In 1788 the French politician and revolutionary Jacques Pierre Brissot de Warville (who had studied under Fourcroy some years before and who had later visited Priestley in England) spent six months in America and on a visit to Harvard

\section{Samuel Latham Mitchill}

\section{4-1831}

Also a graduate of the University of Edinburgh, Mitchill was born on Long Island of a Quaker family. On his return to America he was appointed in 1792 as Professor of Chemistry in Columbia College, New York, where "he first taught the reformed Chymistry of the French" and as teacher, author and as editor of the Medical Repositoryan early scientific journal he founded in 1797-laboured to explain the new chemical theories of Lavoisier and his associates to American scientists. He also began the study of the mineralogy of America was delighted to find that the Professor of Chemistry and Materia Medica, Dr Aaron Dexter

"was reproducing the experiments conducted by our French chemists. He was using the excellent work by my own respected teacher, Dr. Fourcroy, which taught him the rapid strides that this science has lately made in Europe"

Lavoisier's theory of combustion required a revision of the list of chemical elements as many of the substances looked upon as compounds by the phlogistonists had now been shown to be elements, and together with Fourcroy, De Morveau and Berthollet he developed a completely new system of chemical nomenclature that would clearly define elements, oxides, acids and alkalis and that could be used to indicate the name of substances yet to be discovered. This was published as Méthode de Nomenclature Chimique in 1787, and was translated into English as well as into German, Italian and Spanish, while one or two pirated editions had made their appearance in America by 1791.

\section{The New Chemistry in America}

In the introduction of the new system into American scientific circles the major part was played by Samuel Latham Mitchill, another student of Black's at Edinburgh University. Appointed Professor of Chymistry, Natural History and Agriculture at Columbia College in 1792, Mitchill felt that it was essential for the new terminology to be understood and adopted as it was being in Europe, and he not only taught the "reformed chemistry of the French" in his lectures but, in 1794, he published

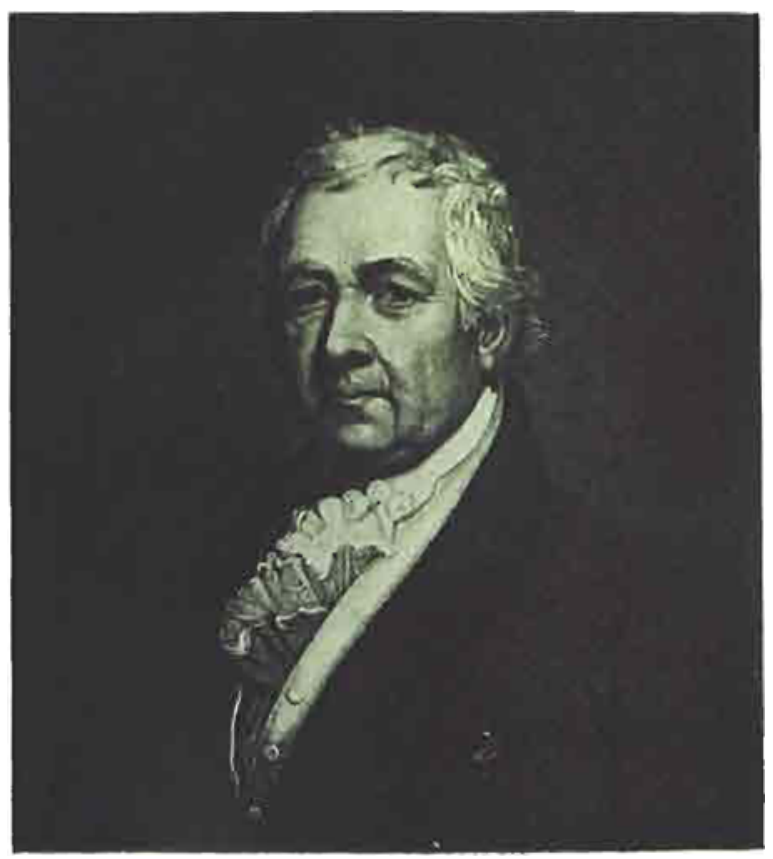


his own Nomenclature of the New Chemistry, which he considered

"a beautiful specimen of the analytic method, and an arrangement happily calculated to systematise and simplify the study of chemistry"

In the same year Priestley arrived in the United States to escape from political persecution in England-while he was on the Atlantic Lavoisier was guillotined by the terrorists of the French Revolution-and the phlogiston controversy began to occupy a great deal of the time and attention of the leading American chemists. Priestley precipitated matters by publishing in 1796 the first part of his famous pamphlet Considerations on the Doctrine of Phlogiston and the Decomposition of Water, the second part following a year later. But in that year Mitchill had founded a periodical, The Medical Repository, which at once became a forum for the arguments on both sides. While Mitchill's views were definitely anti-phlogiston, his admiration for Priestley caused him to adopt an impartial attitude in his editorial capacity, and he published or reviewed several papers by Priestley together with contributions opposing the older views from John Maclean, Professor of Chemistry at the College of New Jersey at Princeton (and another Scot, this time from the University of Glasgow), James Woodhouse, who had succeeded his old teacher Rush as Professor of Chemistry at the University of Pennsylvania (Priestley himself having declined the offer of the chair), and from Pierre Auguste Adet, one of Lavoisier's circle who had come to Philadelphia as Ambassador to the United States. Priestley, fighting a stubborn rearguard action, complained:

"In America also, I hear of little else. It is taught, $I$ believe, in all the schools on this continent, and the old system is entirely exploded".

\section{The First Chemical Society}

James Woodhouse, a native of Philadelphia, had played a further and major part in the world of science by founding (and becoming its first and only President) the Chemical Society of Philadelphia in 1792. This, apart from two student societies in the Universities of Glasgow and Edinburgh, was the first chemical society in the world, although it survived only until about 1810 . One of its early objectives was the collection and analysis of minerals and oresincluding a gold ore from Virginia "from ten pennyweights of which three grains of gold, twenty-four carats fine, have been extracted"-but the major interest in its affairs from today's point of view lies in two of its "Annual Orations". In 1797 the Society invited Thomas Peters Smith, then only twenty years of age, to deliver the first of these reviews, but instead of confining himself to progress made during the previous year he dealt with the whole history of chemistry. This was so well received that it was decided to publish it as a pamphlet, $A$ Sketch of the Revolutions in Chemistry. This is the earliest known publication of a chemical society in America, and similarly the first account of the history of chemistry to be published there. One significant paragraph from this very young man read:

"The only true bases on which the Independence of our country can rest are Agriculture and Manufactures. To the promotion of these nothing tends in a higher degree than Chemistry. It is to a general diffusion of a knowledge of this science, next to the virtue of our countrymen, that we are to look for the firm establishment of our Independence."

Smith left for Europe in 1800 and spent many months visiting scientists and manufacturing plants in Germany, Sweden, France and England, but unfortunately his promising career was cut short by the accidental bursting of a gun on the vessel that was bringing him back to America in 1802 .

The second annual oration, given in January 1801 by Felix Pascalis, a French physician who had left Santo Domingo to settle in Philadelphia and who was now a Vice-President of the Society, was a somewhat rambling survey of the improvements made by chemistry in the arts and manufactures, but it contained the following paragraph almost as an afterthought:

"In the Philadelphia Laboratories new experiments have been lately instituted, relative to the tremendous effects of the fulminating mercury. The galvanic influence also, that astonishing phenomenon of PERPETUAL MOTION, has been minutely investigated by Professor Woodhouse, both through the METALIIC PILE and the CHAIN OF CUPS OF VOLTA"

Volta's famous letter to Sir Joseph Banks, then the President of the Royal Society, was read to the Society on June 26 th, 1800 , but obviously it had prompted investigations in America as rapidly as had been the case in Europe, and the major developments brought about by a continuous source of current were under way.

In his time, Woodhouse, who unfortunately died at the early age of 39 , was to inspire Benjamin Silliman, who was appointed Professor of Chemistry at Yale in 1802 and who opened another new chapter in American chemistry.

\section{Three Presidents of the \\ American Philosophical Society}

Since 1770 the revived American Philosophical Society, modelled after the Royal Society, and the culminating achievement of all the efforts of the colonial era towards such an organisation, had been accepted on both sides of the Atlantic as an effective forum for the publication of mature scientific work. During the next forty-five years the Society had only 


\section{Thomas Jefferson \\ 1743-1826}

Third President of the American Philosophical Society-a position he leld for seventeen years-and third President of the United States, Jefferson held firmly that Amerien should benefit from everything that seience had to offer and laboured tirelessly to keep his country abreast of European progress. The wide scientific interests of a man of such high international reputation also helped to raise the status of science in the early days of the republic

three Presidents-each of them a man of outstanding talents and personality, but each different in many respects.

From the date of its revival in 1769 Franklin had been appointed President, and he retained the office until his death in 1790. (After his return from Paris in 1785 meetings were frequently held in his house.) He was followed by his friend, David Rittenhouse, the self-taught watchmaker, mathematician and astronomer, who held office until his death in 1796. Rittenhouse did not enjoy the stimulus of residence in Europe, or of an extensive correspondence with European scientists, but apart from his remarkable achievements in astronomy he did make one significant contribution-little noticed in modern timesto the physical sciences. In 1781 he read to the American Philosophical Society a paper, "An Account of Some Experiments on Magnetism", in which he put forward a perceptive theory of magnetism much in advance of his time:

"These magnetical particles I suppose have each a north and a south pole, and that they retain their polarity, however the metal may be fused or otherwise wrought. In a piece of iron which shows no signs of magnetism these magnetical particles lie irregularly, with their poles pointing in all possible directions, they therefore mutually destroy each others effects. By giving magnetism to a piece of iron we do nothing more than arrange these particles."

Rittenhouse's reputation as a scientist was second only to that of Franklin in America. He was elected a Fellow of the Royal Society, but during the war he was much occupied with the defence of Pennsylvania -among other things he supervised the casting of guns and the manufacture of gunpowder-and then with the drafting of the constitution. The last three years of his life were spent as Director of the newlyfounded United States Mint in Philadelphia, a part of his career in which he followed in the footsteps of his great hero Isaac Newton.

On the death of Rittenhouse the American Philosophical Society turned to Thomas Jefferson to

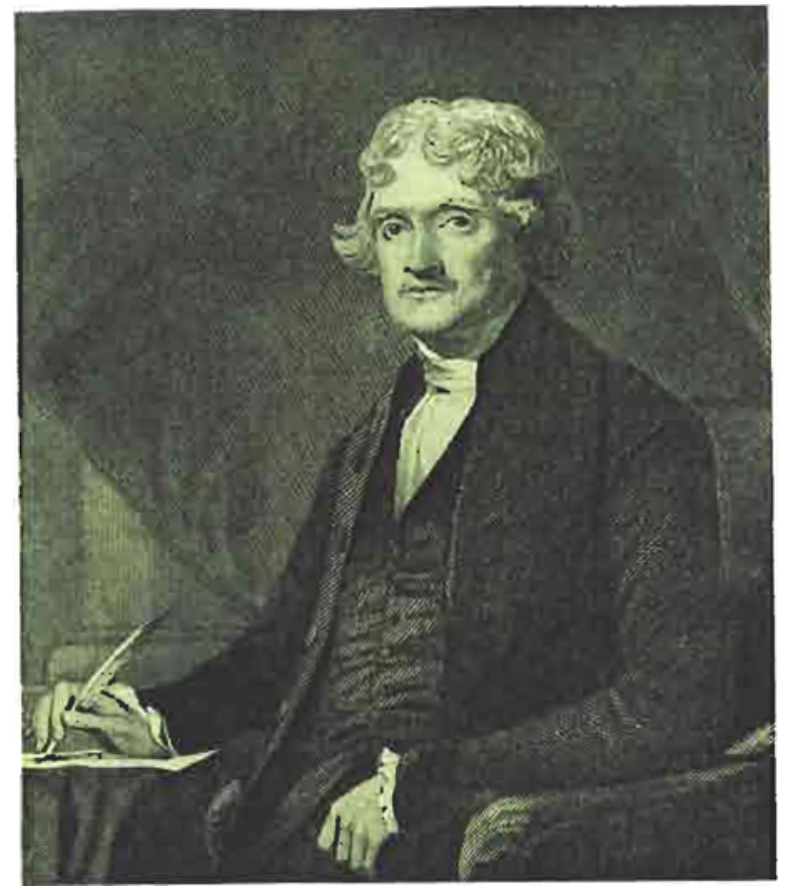

fill the Presidential chair. Jefferson, who had been actively associated with the society since its revival in 1769 , had not only a formidable and wide-ranging intellect but also a keen interest in the contribution that European science could make to American progress and prosperity. Educated at William and Mary College in his native Virginia, where William Small had been appointed Professor of Mathematics and Natural Philosophy in 1758 , he was probably set on his path by this enthusiastic and skilful teacher from Scotland, and in fact he wrote in his autobiography that Small's appointment "was my great good fortune, and probably fixed the destinies of my life". (Small returned home in $\mathbf{1 7 6 4}$ and began a second important career as the influential friend first of James Watt, to whom he introduced Matthew Boulton, and then of that remarkable band of English scientists and industrialists, the famous Lunar Society, who served as the guiding influence in the Industrial Revolution.)

In 1785 Jefferson succeeded Franklin as ambassador in Paris, and found himself in the midst of intense activity in chemistry. Holding firmly to his view that science should be useful to mankind, he once argued with the great French naturalist Buffon who "affected to consider chemistry but as cookery", and defended it resoundingly:

"Chemistry is among the most useful of sciences, and big with future discoveries for the utility and safety of the human race"

Some years later, in a letter to Dr. Thomas Ewell for the preface of the latter's Plain Discourses on the Laws 
or Properties of Matter, he wrote rather caustically:

"Of the importance of turning a knowledge of chemistry to household purposes I have been long satisfied. The common herd of philosophers seem to write only for one another. The chemists have filled volumes on the composition of a thousand substances of no sort of importance to the purposes of life"

During the five years he spent in France-and in travelling widely in Europe-Jefferson served almost as a one-man bureau of information in keeping his American friends abreast of the progress of European science, sending home books and journals to Rittenhouse, Franklin and Rush and to the colleges of Yale, William and Mary, Harvard and Philadelphia. He returned in $\mathbf{1 7 8 9}$ more than ever determined to encourage scientific activity and to obtain proper recognition for American scientists. His own prestige, and his appointment as Secretary of State in Washington's first cabinet and later of course as Vice-President and finally as the third President of the United States, helped materially in raising the standing of science in his country and its significance to the community.

Jefferson also amassed the finest library of his time, which eventually became the nucleus of the Library of Congress, just as the library of George IIIhimself something of an amateur scientist-became the nucleus of the British Museum Library!

But despite George III and some of his ministers, relations between scientists in the colonies and those in the mother country were not altogether impaired, and the spirit of encouragement was renewed after the negotiation of peace with England in which Franklin had played the major role. Writing to Franklin in $1783 \mathrm{Sir}$ Joseph Banks, the greatest President the Royal Society had elected for many years, looked forward to the prospect of freer communications, and went on:

"My sincere congratulations on the return of peace, which in whatever form she is worshipped, bad peace or good peace, never fails to prove herself the Faithful nurse of Science."

\section{Facsimile of the Peace Treaty}

\section{AN ATTRACTIVE APPLICA'TION OF GOLD ELECTROFORMING}

No less important than the Declaration of Independence was the Peace Treaty signed at the York Hotel in Paris between England and the United States in September 1783. One unusual and attractive feature of the bicentennial celebrations is a facsimile of this treaty, printed on handmade paper similar to that of the original document, bound in leather, and with the eight corner pieces and the central plaque on the covers and the seals of the signatories-John Adams, Benjamin Franklin, John Jay and the English pleniopotentiary, Franklin's friend David Hartley-reproduced in high purity gold by electroforming from the originals. A modified sulphite bath was used, and all the gold ietms are hall-marked.

A limited number of copies of this collector's item will be produced later in the year and will be available from B.J.S. Electro-Plating Company Ltd, 348 Kilburn High Road, London NW6.

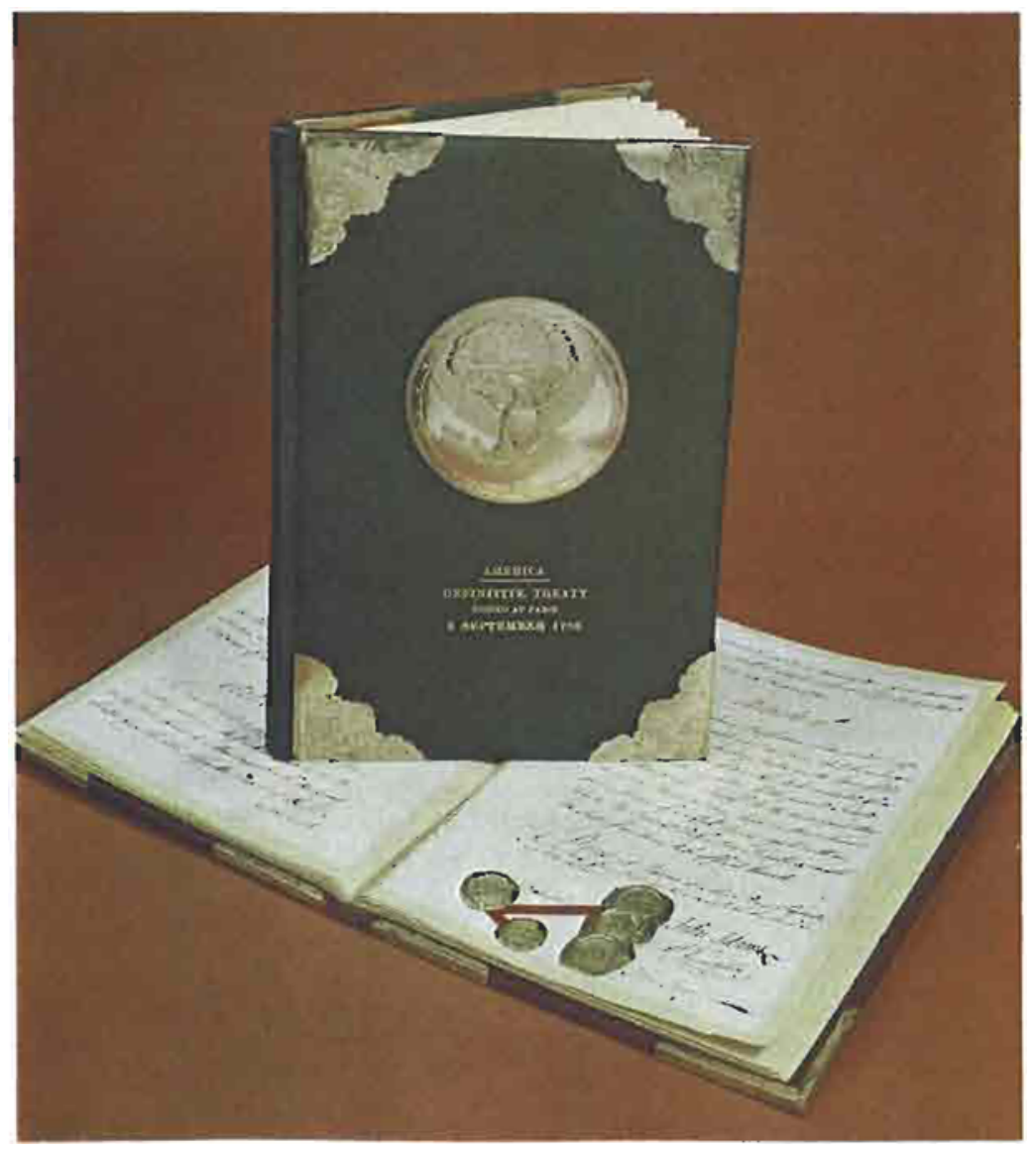

